\title{
MULTI-ANNUAL AND SEASONAL PATTERNS OF WATERBIRD ASSEMBLAGES IN A MEDITERRANEAN COASTAL LAGOON (EL MELLAH LAGOON) OF NORTHEASTERN ALGERIA
}

\author{
SALAH TELAILIA ${ }^{1 *}$, LAMIA BOUTABIA ${ }^{1}$, MOHAMED DHAYA EL-HAK KHEMIS ${ }^{2}$, \\ ALI ELAFRI $^{3}$, NAWEL DJEBBARI ${ }^{4}$
}

\begin{abstract}
${ }^{1}$ Laboratory of Agriculture and Ecosystem Functioning, Department of Agronomy Sciences, Faculty of Natural and Life Sciences, Chadli Bendjedid University, El Tarf, P.O. Box 73, 36000, El Tarf, Algeria; e-mail: s_azzidz@yahoo.fr; b_lamiadz94@yahoo.fr

${ }^{2}$ Department of Biology, Faculty of Sciences, Badji Mokhtar University, Annaba, P.O. Box 12, 23000, Annaba, Algeria; e-mail: khemis.dhaya@yahoo.com

${ }^{3}$ Department of Natural and Life Sciences, Institute of Science and Technology, Abdelhafid Boussouf University, Mila, 43000, Mila, Algeria; e-mail: a.elafri@centre-univ-mila.dz

${ }^{4}$ Laboratory of Ecobiology for Marine Environment and Coastlines, Faculty of Science, Badji Mokhtar University, Annaba, P.O. Box 12, 23000, Annaba, Algeria; e-mail: djebari_nawel@yahoo.fr
\end{abstract}

${ }^{*}$ Author for correspondence

\begin{abstract}
Telailia S., Boutabia L., Khemis El-Hak M.D., Elafri A., Djebbari N.: Multi-annual and seasonal patterns of waterbird assemblages in a Mediterranean coastal lagoon (El Mellah lagoon) of Northeastern Algeria. Ekológia (Bratislava), Vol. 36, No. 2, p. 146-158 , 2017.

Recently, Mediterranean coastal lagoons have raised considerable environmental concerns. Long-term studies of seasonal changes in waterbird assemblages are therefore extremely important in terms of ecological relevance and conservation of these sensitive ecosystems. An ornithological survey of four years was carried out in a typical costal wetland (El Mellah lagoon) of Northeastern Algeria. Intra-seasonal comparison of waterbird assemblages (diversity indices) demonstrates clear changes between the wintering and the breeding periods. It seems that the first one was rich in term of species number than the second season (43 against 24). In contrast, the breeding seasons were more equilibrate (high values of Simpson, Shannon and evenness index). Additionally, curves in the diversity/dominance diagram revealed that both wintering and breeding assemblages share the same characteristics of community structure, few dominant species (with intermediate relative abundance) and many rare species with the relative abundance lower than 0.1. Invertebrates ( 25 species) and piscivorous ( 11 species) are the most abundant guilds over the four years of study (no significant differences among years have been calculated). The marked decline in bird species diversity recorded in this study (in comparison with previous studies) is mainly due to salinity oscillations (due to aquaculture activities) and may be of concern to wetland managers and it might be useful to provide some guidelines about the characteristics that coastal lagoons have to follow in the construction process to enhance the biodiversity.
\end{abstract}

Key words: bird assemblages, monitoring, diversity indices, El Mellah lagoon, Algeria. 


\section{Introduction}

Coastal lagoons are among the most productive ecosystems in the world. They are typical zones between the continent and the sea where the existence of ecological gradients, due to the transition from continental to marine domain creates peculiar ecological conditions that characterize these ecosystems (Pérez-Ruzafa et al., 2011; Cataudella et al., 2015). Recently, Mediterranean coastal lagoons have raised considerable environmental concerns: land claiming, aquaculture and capture fishery activities and pollution have strongly modified both the structure and the functioning of these sensitive ecosystems (Kerambrun, 1986; Cataudella et al., 2015). This is also seriously affecting the richness and population abundance of avian species, given that birds are critical components of the lagoon ecological processes (e.g., web food) (Aymerich, Celdran, 2011). The aquatic bird fauna is in fact extremely important in terms of ecological relevance and conservation in all the lagoons of the Mediterranean region and several aspects of their ecology make them useful for understanding the wetland dynamics (Josens et al., 2012). Birds associated with aquatic habitats have been shown to track changes in such natural (water level and lake productivity) or anthropogenic environmental factors, both on short (months) and long (years) temporal scales and at both the species and community levels (Almaraz, Amat, 2004; Rendón et al., 2008; Josens et al., 2012). Long-term studies of animal populations have been often considered of paramount importance in understanding the frequency, duration and amplitude of variations in the ecological systems. For instance, only the long-term studies on distribution and density of animal populations highlighted the effects of environment changes (Clutton-Brock, Sheldon, 2010); the management decisions based on short-term studies may not reflect the biology of species involved (Scarton, Valle, 2015). Given this, the long-term studies of Algerian coastal wetlands are scarce. We aim in this paper to provide a multi-annual data on waterbird assemblage fluctuations in one of the most typical coastal lagoon of Northeastern Algeria (El Mellah lagoon). With a description of some population trends and waterbird community characteristic (diversity indices and diversity/dominance diagrams), there by highlighting the eventual impacts of aquaculture activities and fishery exploitations (the results were discussed with data from previous available literature).

\section{Material and methods}

\section{Study area}

El Mellah lagoon is located in the extreme eastern Algeria near the Tunisian-Algerian border in the region of El Kala (36 $\left.53^{\prime} 50^{\prime} \mathrm{N}, 8^{\circ} 19^{\prime} 30^{\prime} \mathrm{E}\right)$. It appears as an elongated ovoid bowl in a dense forest cover natural site (Fig. 1). It is connected to the sea by a channel $900 \mathrm{~m}$ long and 1 to $10 \mathrm{~m}$ wide, and an average depth of $3.5 \mathrm{~m}$. This lagoon is not only fuelled by marine waters, which are partly responsible for its brackish nature, but also by the gentle waters of three rivers: R'kibet Northwest, and South El Mellah and Belaroug (Arrignon, 1963; Thomas et al., 1973; Guelorget et al., 1989) (Fig. 1).

\section{Methods}

The study area was visited twice a month from September 2007 to August 2011; the total time spent in the field amounting to $576 \mathrm{~h}$, about $6 \mathrm{~h}$ being spent per visit. Bird counts were done using a 20-40.60 telescope (Konus Spot- 


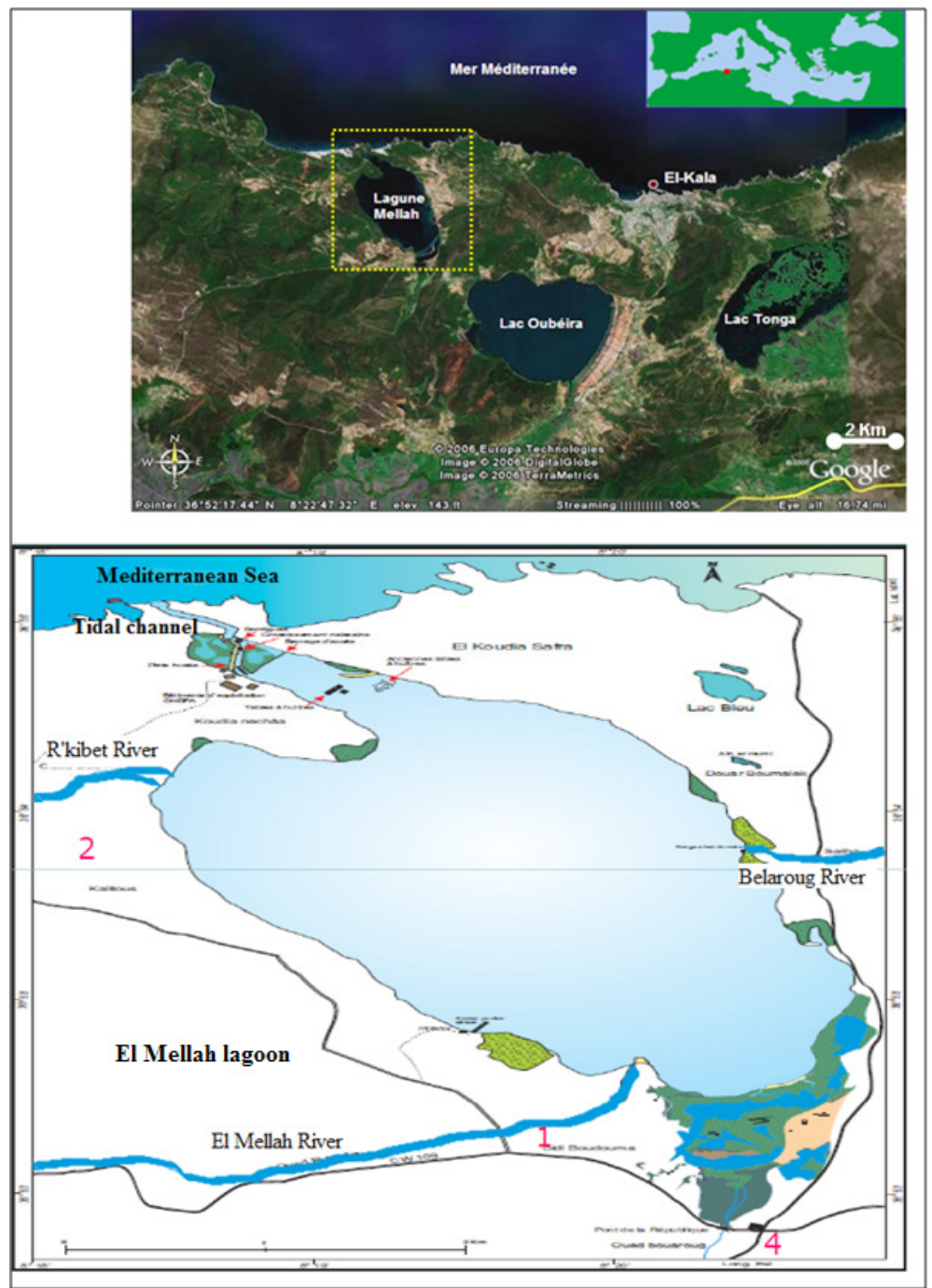

Fig. 1. Location of El Mellah lagoon (Northeast Algeria) and detailed map shows the three rivers and the tidal channel.

ting Scope). Count was done according to two methods depending on the population size: when the number did not exceed 200 individuals, the birds were counted individually; if the number exceeded 200 individuals, the birds were estimated (Blondel, 1975; Legendre L., Legendre P., 1979).

\section{Data analysis}

The structure of bird stands in the El Mellah lagoon was assessed using ecological parameters (abundance, richness, diversity). So, for each count session, we calculated species richness, and relative abundance. During each visit, the 
relative abundance (\%) of bird species was estimated according to the following expression: $\mathrm{n} / \mathrm{N}$. 100, where $\mathrm{n}$ is the count of a particular bird species and $\mathrm{N}$ is the total number of individuals counted for all species (during each count session) (Dajoz, 2006). We also calculated the classical diversity indices, such as the Simpson index, D (according to the formula $\mathrm{D}=1-\{\Sigma \mathrm{ni}(\mathrm{ni}-1) / \mathrm{N}(\mathrm{N}-1)\}$, where ni is the total number of birds of each individual species; $\mathrm{N}$ is the total number of birds of all species), the Shannon diversity index $\mathrm{H}^{\prime}$ (according to the formula $\mathrm{H}^{\prime}=[\Sigma \mathrm{Pi} \ln \mathrm{Pi}]$, where, $\mathrm{H}^{\prime}$ = Diversity Index; $\mathrm{Pi}=$ is the proportion of each species in the sample; and Evenness (E) (Pielou index) [Shannon diversity index $\left(\mathrm{H}^{\prime}\right)$ divided by the maximum diversity $(\ln S)$, $\mathrm{S}$ being the total number of species recorded during each visit]. The index of evenness shows the number of individuals distributed among species. When all species in a sample are equally abundant, the value of evenness index is one, but it decreases towards zero when the relative species abundance becomes uneven (Okpiliya, 2012). The species abundance distribution was visualized on the rank/abundance plot with species plotted from the most to the least abundant (Magurran, 2004; Battisti et al., 2009).

The Kruskal-Wallis test was used to see the differences in the abundance values, to verify changes by years and months. The one-way ANOVA test was used to look at intra-annual and seasonal changes in the diversity variables. Also, to obtain trends on a representative data set, for each species, a mobile mean and a tendency line was obtained. We assumed 5 and $1 \%$ as alpha levels. For statistical analyses, we used the software SPSS 13.0 for Windows.

\section{Results}

\section{Community size and diversity}

In the 96 censuses carried out, the mean values of individuals (all species included) were estimated at $853 \pm 53$ and $74 \pm 2$ during the wintering and the breeding seasons respectively, and a total of 44 species ( 43 in winter and 24 in summer) with different trophic niches were identified at El Mellah lagoon over the four study years. The best-represented guilds were the Invertebrates (25 species) and the Piscivorous (11 species). The remaining groups: the Omnivorous, the Plants, the Planktons and the Vertebrates were less represented (3, 2 and 1 species respectively). Among the guilds, Piscivorous and Invertebrates were the most abundant guilds both in the wintering and the breeding seasons, comprising 85 and $80 \%$ of all surveyed individuals respectively, followed by the Plant-eaters (18 and $12 \%$ of all birds respectively in the wintering and the breeding seasons) (Fig. 2). The other guilds were less represented during all seasons. Between the species comparison, Great cormorant $(37.93 \%$ of all surveyed individuals), Black-headed gull (17.20\% of all birds) and Sandwich tern Chlidonias hybrid (13.62\% of all birds) were the most abundant in wintering. In contrast, the breeding seasons were dominated by Yellowlegged gull (15.54\%) and Eurasian coot Fulica atra (11.26\%), followed by Little egret Egretta garzetta, Squacco heron, Little grebe, Great crested grebe, and Black-winged stilt (Table 1).

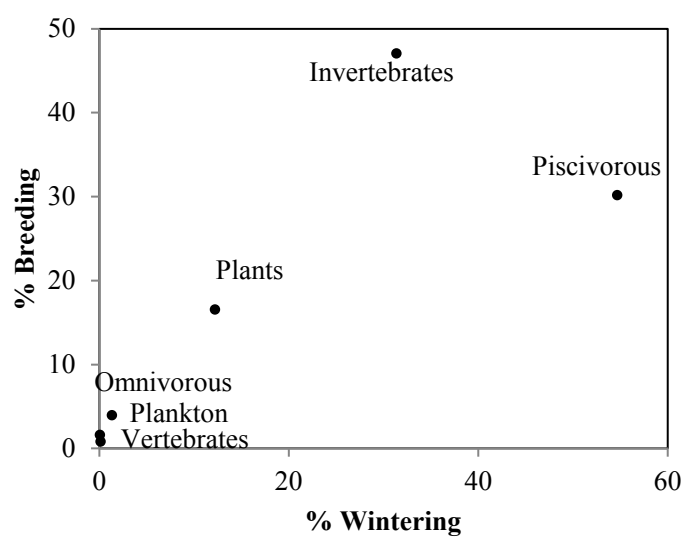

Fig. 2. Scatterplot of different waterbird trophic groups according to their abundance proportion in the wintering and the breeding seasons in El Mellah lagoon from January 2007 to December 2011 (values are presented as means of four years). 
$\mathrm{T}$ a b le 1. Trophic groups, relative abundance, species richness and total abundance of aquatic birds occurring at $\mathrm{El}$ Mellah lagoon from January 2007 to December 2011 (values are given as means of four years).

\begin{tabular}{|c|c|c|c|c|c|}
\hline Trophic group & Species & Phenological status & Wintering & Breeding & Conservation status \\
\hline \multirow{11}{*}{ Piscivorous } & Egretta garzetta & $\mathrm{R}$ & 1.33 & 7.41 & L.C. \\
\hline & Pandion haliaetus & $\mathrm{R}+\mathrm{WM}$ & 0.25 & 1.63 & L.C. \\
\hline & Larus fuscus & WM & 0.06 & 0.00 & L.C. \\
\hline & Ichthyaetus audouinii & $\mathrm{R}$ & 0.04 & 0.34 & L.C. \\
\hline & Larus michahellis & $\mathrm{R}$ & 1.93 & 15.54 & L.C \\
\hline & Chroicocephalus genei & $\mathrm{R}$ & 0.07 & 0.27 & L.C \\
\hline & Phalacrocorax carbo & WM & 37.93 & 0.00 & L.C \\
\hline & Chlidonias hybrida & $\mathrm{R}$ & 0.05 & 0.56 & LC \\
\hline & Ardea cinerea & $\mathrm{R}+\mathrm{WM}$ & 0.52 & 1.09 & LC \\
\hline & Ardea purpurea & SM & 0.03 & 3.16 & LC \\
\hline & Chroicocephalus ridibundus & WM & 17.20 & 1.43 & LC \\
\hline \multirow{26}{*}{ Invertebrates } & Limosa lapponica & WM & 1.58 & 0.00 & NT \\
\hline & Calidris ferruginea & WM & 0.03 & 0.00 & NT \\
\hline & Calidris minuta & WM & 0.08 & 0.00 & LC \\
\hline & Calidris alpina & WM & 0.10 & 0.00 & LC \\
\hline & Tringa nebularia & WM & 0.69 & 0.00 & LC \\
\hline & Tringa erythropus & WM & 0.10 & 0.00 & LC \\
\hline & Tringa ochropus & WM & 0.13 & 0.00 & LC \\
\hline & Tringa totanus & WM & 0.23 & 0.00 & LC \\
\hline & Actitis hypoleucos & $\mathrm{R}$ & 0.24 & 2.21 & LC \\
\hline & Ardeola ralloides & $\mathrm{R}$ & 0.07 & 7.89 & LC \\
\hline & Himantopus himantopus & $\mathrm{R}$ & 0.75 & 6.51 & LC \\
\hline & Glareola pratincola & WM & 0.02 & 0.00 & LC \\
\hline & Charadrius hiaticula & WM & 0.11 & 0.00 & LC \\
\hline & Ardea alba & WM & 0.41 & 0.00 & LC \\
\hline & Charadrius alexandrinus & $\mathrm{R}$ & 0.37 & 3.93 & LC \\
\hline & Podiceps nigricollis & $\mathrm{R}$ & 4.83 & 0.61 & LC \\
\hline & Tachybaptus ruficollis & $\mathrm{R}$ & 1.08 & 7.68 & LC \\
\hline & Podiceps cristatus & $\mathrm{R}$ & 2.36 & 7.77 & LC \\
\hline & Haematopus ostralegus & $\mathrm{R}$ & 0.02 & 0.58 & NT \\
\hline & Marmaronetta angustirostris & $\mathrm{R}$ & 0.16 & 5.07 & VU \\
\hline & Thalasseus sandvicensis & WM & 13.62 & 0.00 & LC \\
\hline & Gelochelidon nilotica & WM & 0.06 & 0.00 & LC \\
\hline & Sterna hirundo & SM & 0.00 & 2.04 & LC \\
\hline & Arenaria interpres & WM & 0.03 & 0.00 & LC \\
\hline & Charadrius dubius & WM & 0.52 & 0.00 & LC \\
\hline & Pluvialis apricaria & WM & 0.16 & 0.00 & LC \\
\hline \multirow[t]{3}{*}{ Omnivorous } & Anas platyrhynchos & $\mathrm{R}$ & 0.11 & 3.81 & LC \\
\hline & Aythya fuligula & WM & 0.34 & 0.00 & LC \\
\hline & Aythya ferina & WM & 0.71 & 0.00 & VU \\
\hline Plankton & Phoenicopterus roseus & $\mathrm{R}$ & 0.02 & 0.43 & LC \\
\hline \multirow{2}{*}{ Plants } & Fulica atra & $\mathrm{R}$ & 9.61 & 11.26 & LC \\
\hline & Gallinula chloropus & $\mathrm{R}$ & 1.94 & 7.76 & LC \\
\hline Vertebrates & Circus aeruginosus & $\mathrm{R}$ & 0.10 & 0.41 & LC \\
\hline Number of species & & 43 & 24 & & \\
\hline Mean abundance & & $853( \pm 53)$ & $74( \pm 2)$ & & \\
\hline
\end{tabular}

Notes: R - resident; WM - winter migrant; SM - summer migrant; LC - least concern; NT - near threatened; VU - vulnerable. 


\section{Ecological status of birds}

Migratory species accounted for 25 of all recorded birds. They were represented by 23 winter migrants' species and tow summer migrants. Sedentary status was represented by 19 species of all recorded birds (Table 1). In accordance with the BirdLife Checklist Version_7 (2014), we have two Near Threatened species Bar-tailed godwit Limosa lapponica and Curlew Sandpiper Calidris ferruginea and tow Vulnerable Marbled duck Marmaronetta angustirostris and Common pochard Aythya ferina. The remaining species were assigned the status of 'Least Concern' (Table 1).

\section{Trends in community size and diversity}

During the study period (2007-2011) the total number of birds (all species included) in the study area fluctuated following a seasonal trend (similar patterns for all years). Highest values are recorded in October-February (i.e., wintering seasons) and lowest values in MarchAugust (i.e., breeding seasons). Thus, the differences between the mean abundance values per bi-month of each year were statistically significant (2007/2008: K= 20.7; 2008/2009: $\mathrm{K}=22.13 ; 2009 / 2010: \mathrm{K}=21.91 ; 2010 / 2011: \mathrm{K}=21.49$, $\mathrm{p}<0.05)$. Although the tendency line shows a weak decreasing trend from 2007 to 2011 (Fig. 3), total abundance (community size) didn't show a significant fluctuation between years $(K=0.16, \mathrm{p}=0.98)$.

As for the community diversity, variability in species composition (diversity index) among seasons was high $(\mathrm{S}: \mathrm{F}=2.7, \mathrm{p}<0.05 ; \mathrm{H}: \mathrm{F}=124, \mathrm{p}<0.01 ; \mathrm{D}: \mathrm{F}=128, \mathrm{p}<0.01 ; \mathrm{E}: \mathrm{F}=416$, $\mathrm{p}<0.01)$ and similar between years $(\mathrm{S}: \mathrm{F}=0.12, \mathrm{p}=0.94 ; \mathrm{H}: \mathrm{F}=0.05, \mathrm{p}=0.98 ; \mathrm{D}: \mathrm{F}=0.01, \mathrm{p}=$ 0.99; $\mathrm{E}: \mathrm{F}=0.01, \mathrm{p}=0.99)$. So, during the study period, we observed marked intra-seasonal

\section{Total number}

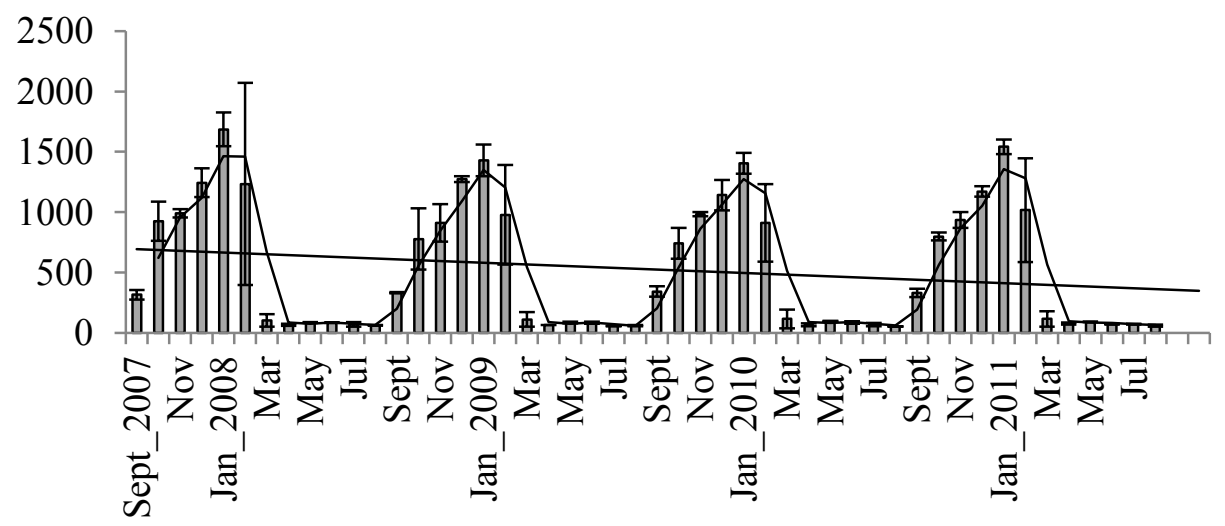

Fig. 3. Mean abundance (and standard deviation) of total number of birds (all species included) in the period September 2007-August 2011. Tendency line and mobile mean are also reported. 

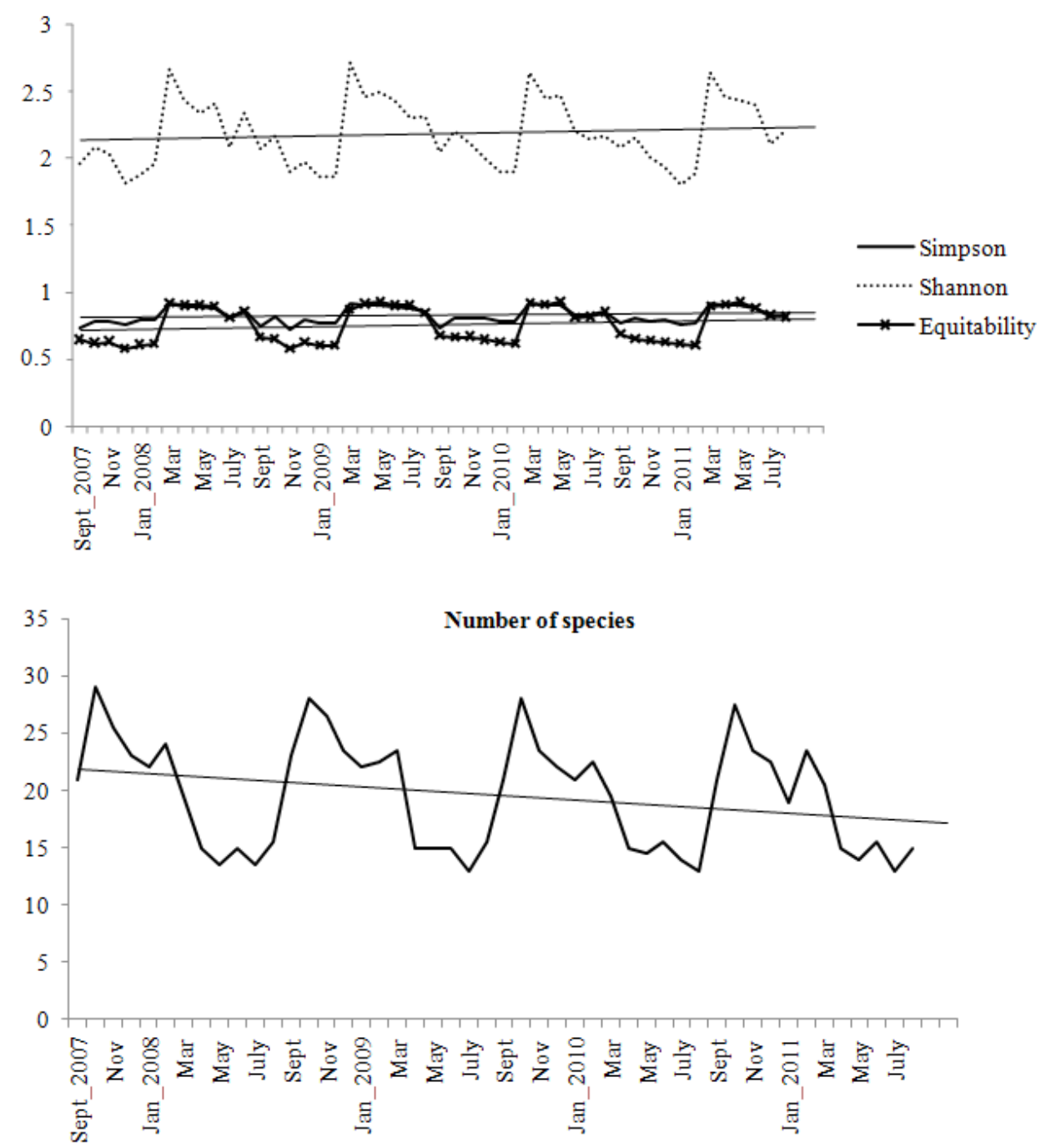

Fig. 4. Inter-annual and intra-seasonal patterns of waterbird diversity indices at El Mellah lagoon from January 2007 to December 2011 (values are presented as means of bimonthly counts).

fluctuation. Generally, all diversity variables peak in the breeding seasons (April to August) and were low in the wintering period (September to March) for all years. In contrast, the number of species peak often in winter and decrease until summer for all years (Fig. 4). Hence, the considered wintering seasons in all years were rich on species, but revealed a noteworthy community organization (less evenness) characterized by the following patterns: one dominant species, a few species with intermediate occurrence frequency ranging from 
0.1 to 0.4 and finally, many rare species with the relative abundance lower than 0.1 (Fig. 5). Dissimilarly, breeding seasons of all years were more equilibrate (if compared with the wintering seasons), since Shannon index are max, and the rank/relative occurrence diagram (Whittaker plot) showed a lower slope compared to the wintering season curves, reflecting an increasing even assemblage (Fig. 5).
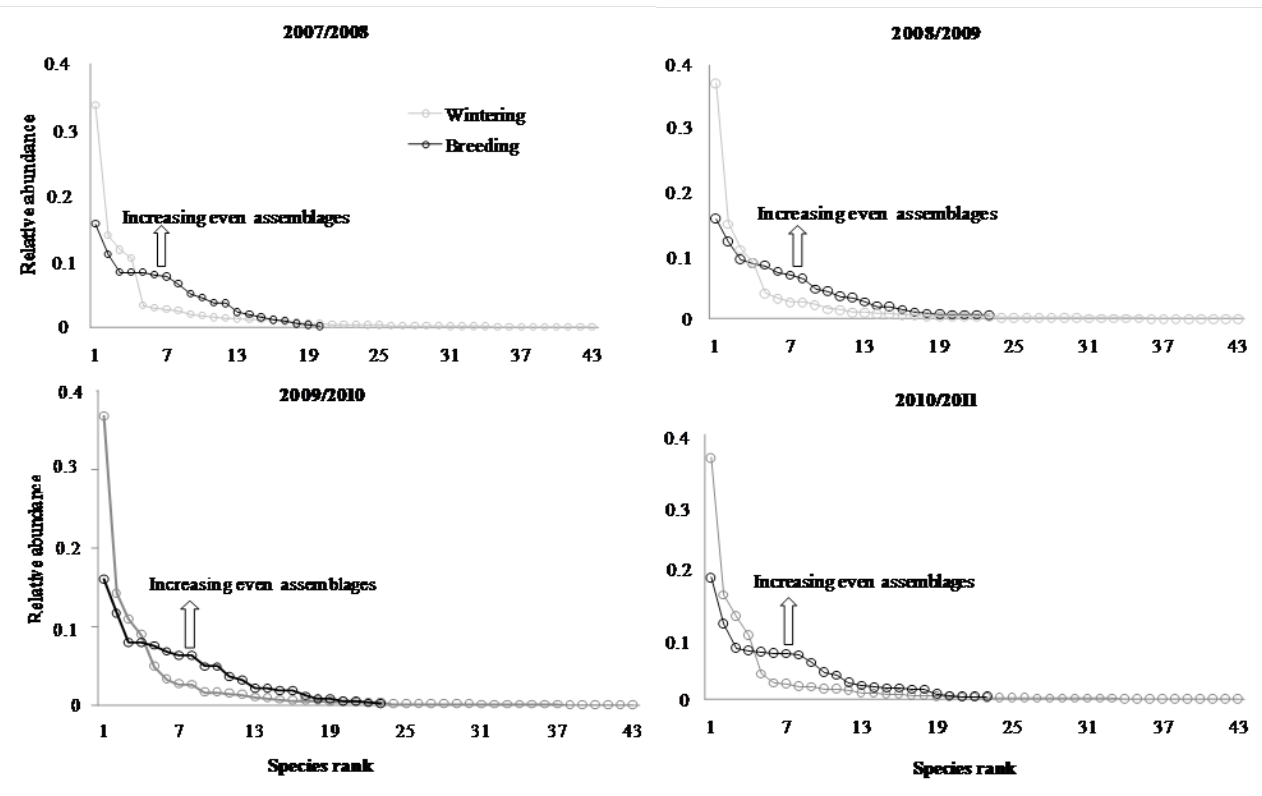

Fig. 5. Species rank/relative abundance diagram (Whittaker plots) of breeding and wintering bird assemblages at El Mellah lagoon during four yearly cycles of study.

\section{Discussion}

Our long-term data highlighted details on bird phenology at inter-annual and intra-seasonal scales. According to the national data on bird phenology in all the wetlands of Algeria [99 species identified by Samraoui B., Samraoui F. (2008)], the study site hosts a diverse avifauna, it was represented by more than half the waterbird species, and it was closer to those obtained in the most diversified wetland of Algeria, Lake Tonga [52 species reported in Elafri et al. (2016)]. Great cormorant, Black-headed gull Sandwich tern that are piscivorous were the most abundant species during the wintering season. In contrast, coots, grebes, gulls and some herons that are almostin vertebrates, were abundant in the breeding seasons. This diversity could be explained by the fact that this area is located along migratory flyways (Palearctic-African migration) of many Palearctic and sub-Saharan species (Delany, Scott, 2006; Samraoui et al., 2011). Until the end of the last century (XX), this lagoon was more 
diversified and species such as Tufted Duck Aythya fuligula, Eurasian Wigeon Anas penelope, Mallards A. platyrhynchos, and Northern Shoveler A. clypeata have been regular visitors of the site (Ochando, Jacobs, 1978a, b; Bellatreche et al., 1982, 1983; Bellatreche, Ochando, 1986, 1987; Bellatreche, Chalabi, 1988; Bellatreche, Lellouchi, 1989; Doumandji et al., 1990; Samraoui, de Bélair, 1998). A point of strength that could explain this decreasing of species richness is the fluctuation in the rate of water exchange between the sea and the lagoon. This brings about fluctuations in salinity due to the tidal channel managements carried out in 1988 (expended it to $20 \mathrm{~m}$ width and $2 \mathrm{~m}$ depth) in order to enhance the water quality for aquaculture purposes (FAO, 1987) [see Chalabi et al.(2002) for more information about changes in the physicochemical water quality]. Such oscillations may create extreme conditions for many taxa and the resulting biodiversity is characterized by a low number of highly specialized species (Cataudella et al., 2015). Also, we have to mention that increasing the water salinity level affects the Potamogeton pectinatus production, there by disturbing the web food of waterbirds whose diet includes a range of fauna items and aquatic plants including ducks (Van Wijk, 1988; Micklin, 1988; Bunn, Arthington, 2002; Kingsford, Thomas, 2004). Our data on waterbird diversity variables and its variability over four years of study highlights this decrease in biodiversity, since we have measured lower values of Simpson, Shannon and evenness markedly in the wintering season. The breeding seasons seem to be more equilibrated than the wintering seasons and some quantitative differences emerged from the diversity/dominance diagram on species occurrence values, where the curve with a shallower slope evidenced an increasing even assemblage (Magurran, 2004). In winter, the high values of certain dominated species (Great cormorant, Black-headed gull, and Sandwich tern), with many 'rare' species, induced a decrease of evenness in the assemblage. Species-specific intrinsic constraints, as phenology and ecology of the wintering and breeding species, may be crucial in determining differences in the seasonal community structure and consequently in the shape of diversity/dominance curves (Battisti et al., 2009). In winter, many species of cormorants, gulls, terns and waders (Charadriformes) are vagrant and follow a scattered distribution pattern throughout the Mediterranean wetlands; on the contrary, during the breeding period, there are less vagrant species and more territorial ones (herons, grebes and coots), usually common and more uniformly spread. Also, food resources availability is crucial in determining the avian abundance and diversity during breeding and post-nuptial seasons (Pirot et al., 1984). Thus, it allows the nesting installation of some vulnerable and sensitive species as Marbled duck Marmaronetta angustirostris, Osprey Pandion haliaetus, Blackwinged stilt Himantopus himantopus and Kentish plover Charadrius alexandrinus (personal and first observations).

The present study allowed us to evaluate the coastal lagoons' bird species diversity and its variability over a long temporal scale. Given that this coastal Mediterranean lagoon supports a high number of waterbirds species, is currently under strong anthropogenic impacts mainly fishing exploitation (Chaoui et al., 2006), and enhancing marine-lagoon water exchanges (salinity oscillations) clearly increase the dominance of piscivorous and invertebrates against plant-eaters, omnivorous, planktons and vertebrates during both wintering and breeding seasons over the four years of study (no inter-annual and intra-annual changes have been recorded) indicating evidently lower community evenness. This work reconfirms the place 
of the El Mellah lagoon as a particularly important wintering area for Palearctic waterbirds. It also emphasises that the local waterbird diversity depends not only on species-specific intrinsic constraints, but also on the intensity of aquaculture activities. Hence, our results may contribute to the improvement of existing or future management plans. It is certainly clear that the El Mellah lagoon is undergoing constant and rapid transformation due to the aquaculture practices. It is well known that these activities may partially mitigate adverse influences of loss and degradation of natural wetlands (Ma et al., 2010).

\section{Conclusion}

This study shows that the waterfowl community has seasonal fluctuations in abundance, diversity and species richness with a predominance of wintering species such as Eurasian coot (Fulica atra), Black-headed gull (Chroicocephalus ridibundus), Sandwich tern (Thalasseus sandvicensis), Great cormorant (Phalacrocorax carbo) and Black-necked grebe (Podiceps nigricollis). The assemblage of several habitats (open water, salt marshes, alluvial cones, etc.) offers privileged sites for the wintering and nesting of certain avian species.

The diversity of invertebrates and fish in the El Mellah lagoon can be explained by the gradient of spatial and temporal variations of the salinity of water and the presence of swamps and alluvial cones playing the role of nursery also for fish as well as for invertebrates. Considered as an integral reserve and a Ramsar site, the El Mellah lagoon is a real conflict between the managers of the El Kala National Park and the operators of this lagoon. So, the management plans should pay special attention to those species (waterbirds) that are particularly affected. Farmers and aquaculture practices must develop new agri-environment schemes to conceal their aquaculture practices with the conservation of environment. Therefore, it might be useful to provide some guidelines about the characteristics that coastal lagoons should follow in the construction process to enhance biodiversity. However, further investigations of bird foraging behaviour and habitat selection processes are necessary to more profoundly understand the role of habitat modification by aquaculture impacts (salinity fluctuations) activity in shaping the local waterbird communities in this important lagoon at similar sites around the Algerian coast.

\section{References}

Almaraz, P. \& Amat J.A. (2004). Complex structural effects of two hemispheric climatic oscillators on the regional spatio-temporal expansion of a threatened bird. Ecol. Lett., 7, 547-556. DOI: 10.1111/j.1461-0248.2004.00612.x.

Arrignon, J. (1963). Contribution à l'inventaire des marécages, tourbières et autres zones humides d'Algérie. Ann. Cent. Rech. Exp. Forêt. Alger, 5, 30-32.

Aymerich, R.F. \& Celdran P.F. (2011). Waterbirds as bioindicators in Coastal Lagoons: Background, potential value and recent research in Mediterranean areas. In A.G. Friedman (Ed.), Lagoons: Biology, management and environmental impact (pp. 153-184). Nova Science Publisher.

Battisti, C., Malavasi, R. \& Carpaneto G.M. (2009). Breeding and wintering bird assemblages in a Mediterranean wetland: a comparison using a diversity/dominance approach. Vie Milieu, 59(1), 1-6.

Bellatreche, M., Desmet, K., Malher, F. \& Ochando B. (1982). Recensement hivernal annuel des oiseaux d'eau. Algérie, 1982. INA, Départ. Zool. Agri. Polycopié.

Bellatreche, M., Ochando, B., Benmessaoud, K. \& Desmet K. (1983). Recensement hivernal annuel des oiseaux d'eau. Algérie, 1983. INA, Départ. Zool. Agri. Polycopié. 
Bellatreche, M. \& Ochando B. (1986). Recensement hivernal annuel des oiseaux d’eau. Algérie, 1986. INA, Départ. Zool. Agri. Polycopié.

Bellatreche, M. \& Ochando B. (1987). Recensement hivernal annuel des oiseaux d'eau. Algérie, 1987. INA, Départ. Zool. Agri. Polycopié.

Bellatreche, M. \& Chalabi B. (1988). Recensement hivernal annuel des oiseaux d'eau. Algérie, 1988. INA, Départ. Zool. Agri. Polycopié.

Bellatreche, M. \& Lellouchi M. (1989). Recensement hivernal annuel des oiseaux deau. Algérie, 1989. INA, Départ. Forest. Nat. Fiches de Synthèse.

Blondel, J. (1975). Analysis of waterbird populations. Element of an ecological analysis. I: The method of progressive sampling frequency (E.F.P.). Terre et Vie, 29(4), 533-589.

Bunn, S.E. \& Arthington A.H. (2002). Basic principles and ecological consequences of altered flow regimes for aquatic biodiversity. Environ. Manag., 30, 492-507. DOI: 10.1007/s00267-002-2737-0.

Cataudella, S., Crosetti, D. \& Massa F. (2015). Mediterranean coastal lagoons: sustainable management and interactions among aquaculture, capture fisheries and the environment. Studies and Reviews. General Fisheries Commission for the Mediterranean. No 95. Rome: FAO.

Chalabi, A., Semroud, R. \& Grimes S. (2002). Plan daction stratégique pour la conservation de la diversité biologique en région méditerranée. Rapport National PAS-BIO Algérie, Ministère de l'Aménagement du Territoire et de l'Environnement.

Chaoui, L., Kara, M.H., Faure, E. \& Quignard J.P. (2006). Growth and reproduction of the gilthead seabream Sparus aurata in Mellah lagoon (north-eastern Algeria). Sci. Mar., 70(3), 545-552.

Clutton-Brock, T. \& Sheldon B.C. (2010). Individuals and populations: the role of long-term, individual-based studies of animals in ecology and evolutionary biology. Trends Ecol. Evol., 25(10), 562-573. DOI: 10.1016/j. tree.2010.08.002.

Dajoz, R. (2006). Précis décologie. Paris: Dunod.

Delany, S. \& Scott D. (2006). Waterbird population estimates. Wageningen: Wetlands International.

Doumandji, S., Hariza, A., Khedim, A., Ounada, M., Aoussi, K., Telailia, S., Biche, M., Boukhamza, M., Benkouider, M., Mordji, D., Si Bachir, A., Belabbes, A., Belghit, N. \& Boussentouh K. (1990). Recensements hivernaux d’oiseaux d’eau. Algérie, 1990. I.N.A. Départ. Zool. Agri. Polycopié.

Elafri, A., Halassi, I. \& Houhamdi M. (2016). Diversity patterns and seasonal variation of the waterbird community in Mediterranean wetlands of Northeastern Algeria. Zoology and Ecology, 26(2), 85-92. DOI: $10.1080 / 21658005.2016 .1163865$.

FAO, (1987). Aménagement du chenal du lac Mellah. Rapport FAO/Ministère de l'hydraulique, de l'environnement et des forêts, division de développement des activités hydrauliques et agricoles.

Guelorget, O., Frisoni, G.F., Ximenes, M.C. \& Perthuisot J.P. (1989). Expression biologique du confinement dans une lagune méditerranéenne: le lac Mellah (Algérie). Rev. Hydrobiol. Trop., 22(2), 87-99.

Josens, M.L., Escalante, A.H. \& Favero M.(2012). Diversity, seasonality and structure of bird assemblages associated with three wetlands in the southeastern pampas, Argentina. Ardeola, 59(1), 93-109. DOI: 10.13157/ arla.59.1.2012.93.

Kerambrun, P. (1986). Coastal lagoons along the southern Mediterranean coast (Algeria, Egypt, Libya, Morocco, Tunisia): description and bibliography. Unesco Reports in Marine Science, 34. Paris: Unesco.

Kingsford, R.T. \& Thomas R.F. (2004). Destruction of wetlands and waterbird populations by dams and irrigation on the Murrumbidgee River in arid Australia. Environ. Manag., 34, 383-396. DOI: 10.1007/s00267-004-0250-3.

Legendre, L. \& Legendre P.(1979). Ecologie numérique 2: la structure des données écologiques. Masson, Paris: Les Presses de l'Université du Quebec.

Ma, Z., Cai, Y., Li, B. \& Chen J. (2010). Managing wetland habitats for waterbirds: An international perspective. Wetlands, 30, 15-27. DOI: 10.1007/s13157-009-0001-6.

Magurran, A.E. (2004). Measuring biological diversity. Oxford: Blackwell Science.

Micklin, P.P. (1988). Desiccation of the Aral Sea: a water management disaster in the Soviet Union. Science, 241, 1170-1175. DOI: 10.1126/science.241.4870.1170.

Ochando, B. \& Jacobs P. (1978a). Répartition géographique et importance numérique des Anatidés hivernants en Algérie. Rap. Poly. I.N.A. El Harrach (Algérie).

Ochando, B. \& Jacobs P. (1978b). Recensement hivernal d'Anatidés, Foulques, Limicoles, Grues et Flamants, Algérie 1978. Rap. Poly. INA El Harrach (Algérie).

Okpiliya, F.I. (2012). Ecological diversity indices: Any hope for one again? Journal of Environment and Earth Science, 
2(10), 45-52. www.iiste.org

Pérez-Ruzafa, Á., Marcos, C. \& Pérez-Ruzafa I.M. (2011). Recent advances in coastal lagoons ecology: evolving old ideas and assumptions. Transitional Waters Bulletin, 5(1), 50-74. DOI: 10.1285/i1825229Xv5n1p50.

Pirot, J.V., Chessel, D. \& Tamisier A. (1984). Exploitation alimentaire des zones humides de Camargue par cinq espèces de canards de surface en hivernage et en transit: modélisation spatiotemporelle. Terre et Vie, 39(2), 167-192.

Rendón, M.A., Green, A.J., Aguilera, E. \& Almaraz P. (2008). Status, distribution and long-term changes in the waterbird community wintering in Doñana, south-west Spain. Biol. Conserv., 141, 1371-1388. DOI: 10.1016/j. biocon.2008.03.006.

Samraoui, B. \& de Bélair G. (1998). Les zones humides de la Numidie orientale: bilan des connaissances et perspectives de gestion. Synthèse, 4, 1-90.

Samraoui, B. \& Samraoui F. (2008). An ornithological survey of Algerian wetlands: Important Bird areas, Ramsar sites and threatened species. Wildfowl, 58, 71-96.

Samraoui, F., Alfarhan, A.H., Al-Rasheid Khaled, A.S. \& Samraoui B. (2011). An appraisal of the status and distribution of waterbirds of Algeria: Indicators of global changes? Ardeola, 58(1), 137-163. DOI: 10.13157/ arla.58.1.2011.137.

Scarton, F. \& Valle R. (2015). Long-term trends (1989-2013) in the seabird community breeding in the lagoon of Venice (Italy). Rivista Italiana di Ornitologia, 85(2), 19-28. DOI: 10.4081/rio.2015.232.

Thomas, J.-P., Bougazelli, N. \& Attender M., (1973). Projet de parc national marin, lacustre et terrestre d'El-Kala, Annaba, Algérie. Rapport de création de projet d'un parc national. Ministère de l'hydrologie, de l'environnement et des forêts.

Van Wijk, R.J. (1988). Ecological studies on Potamogeton pectinatus. General characteristics, biomass production and life cycles under field conditions. Aquat. Bot., 31, 211-258. DOI: 10.1016/0304-3770(88)90015-0. 